Ann. Anim. Sci., Vol. 12, No. 3 (2012) 323-333, DOI: 10.2478/v10220-012-0027-1

\title{
EFFECT OF THERMAL STRESS ON REPRODUCTIVE PERFORMANCE PARAMETERS OF SOWS WITH DEFINED GENOTYPE AT THE $R Y R 1$ LOCUS
}

\author{
Marek Babicz ${ }^{1}$, Ewa Skrzypczak ${ }^{2}$, Barbara Rejduch \\ Anna Kozubska-Sobocińska ${ }^{3}$, Anna Chmielowiec-Korzeniowska ${ }^{4}$, \\ Karolina Kasprzak \\ ${ }^{1}$ Department of Pig Breeding and Production Technology, University of Life Sciences in Lublin, \\ Akademicka 13, 20-950 Lublin, Poland \\ ${ }^{2}$ Department of Pig Breeding and Production, Poznań University of Life Sciences, Wołyńska 33, \\ 60-637 Poznań, Poland \\ ${ }^{3}$ Department of Animal Cytogenetics and Molecular Genetics, National Research Institute of Animal \\ Production, 32-083 Balice n. Kraków, Poland \\ ${ }^{4}$ Department of Animal Hygiene and Environment, University of Life Sciences in Lublin, \\ Akademicka 13, 20-950 Lublin, Poland \\ ${ }^{5}$ Department of Breeding and Conservation of Genetic Resources of Cattle, \\ University of Life Sciences in Lublin, Akademicka 13, 20-950 Lublin, Poland
}

\begin{abstract}
The objective of the present research was to determine the influence of ambient air temperature in the farrowing section of a pig facility on chemical composition, colostrum and milk somatic cell counts (SCC), and rearing efficiency of piglets from Polish Landrace (PL) sows with identified genotype at the $R Y R 1$ locus. Subjects were 60 PL sows in the second and third reproductive cycle. Polymorphism at the RYR1 locus was analysed using the PCR-RFLP method. The proportion of $R Y R 1 \mathrm{C} / \mathrm{C}$ and $R Y R 1 \mathrm{C} / \mathrm{T}$ genotypes in each group was 1:1. Three groups of experimental temperatures were established: $\mathrm{I}-22^{\circ} \mathrm{C}, \mathrm{II}-25^{\circ} \mathrm{C}, \mathrm{III}-28^{\circ} \mathrm{C}$. The present study demonstrated that sows kept in periodic high ambient temperature $\left(25^{\circ} \mathrm{C}, 28^{\circ} \mathrm{C}\right)$ showed a relatively long period of farrowing, more aggressive behaviour and overlying. Variability was also found between the groups with respect to litter size and litter weight, chemical composition and SCC of colostrum and milk. The results indicate that elevated ambient temperature during the perinatal period may adversely affect the utility value of sows.
\end{abstract}

Key words: thermal stress, sow, RYR1, reproductive performance

High ambient temperature in a pig facility has a disadvantageous effect on the metabolic processes and swine production traits (Fraser, 1970; Brown-Brandl et al., 2001). A dramatic rise in ambient temperature above the values permissible for 
a certain age group disturbs the animal's heat balance and consequently triggers a response in the form of porcine hyperthermia. This is followed by symptoms such as increased breathing rate, excessive urination and hypersalivation. Overheated lactating sows may show inappetence and decreased reproductive parameters (Christon, 1988; Malmkvist et al., 2009). Breeding and production practices have indicated that particularly susceptible individuals are those genetically sensitive to stress, carriers of mutated T allele of the RYRl genotype (Babicz et al., 2003).

Stress is the body's physiological response to a number of specific stressors, especially of an environmental nature, such as disease, inappropriate feeding, and impaired animal welfare standards resulting, among others, from exceeding the optimal ambient temperature. Responses to the stressors activate a cascade of different adaptive mechanisms; neuronal excitability changes into hyperexcitability with a concomitant increase of blood pressure and body temperature. At this stage, the organism tends to perform environmental adaptation via stimulation of the pituitary-adrenal axis, elevation of plasma glucocorticoid levels, lipolysis activation and supply of energy for the adaptive activities. Prolonged exposure to stress-inducing factors causes a persistently high level of glucocorticoids that results in depressed immune mechanisms, thus disturbing fundamental life and productive processes associated with disease induction (Renaudeau et al., 2010). High temperature adversely affects the results, especially reproduction. Despite Poland's mild climate, there are periods of hot weather, which can lead to overheating of the animal's body and related problems.

It is assumed that the thermal optimum for lactating sows should range between 20 and $22^{\circ} \mathrm{C}$. Exceeding these values implicates decreased reproductive performance of gilts and sows. According to Prunier et al. (1997), high ambient temperatures can cause decreased appetite and milk production, increased mobilization of body processes to reduce heat production, and disruption of the estrous cycle. In their study, Bloemhof et al. (2008) showed that the severity of the body's response to high temperature may be breed specific. This led us to choose the Polish Landrace breed, the meat of which is characterized by high phenotypic and genetic variability (Walkiewicz et al., 2002).

The objective of the present study was to determine the effect of an ambient temperature range of $22-28^{\circ} \mathrm{C}$ in the farrowing unit of a pig facility on the chemical composition and somatic cell count of colostrum and milk as well as rearing efficiency of piglets from Polish Landrace sows of the RYR1 C/C and RYRI C/T genotype.

\section{Material and methods}

The experiment was performed with two replications in 2009-2010 (July and August) at two farms located in the Lublin region. The study included 60 Polish Landrace (PL) sows in the second and third reproductive cycle. The maintenance conditions complied with the animal welfare standards. Sows were housed individually in litter-bed farrowing pens of $4.25 \mathrm{~m}^{2}$ area per pig. 
The feeds used were: all-mash containing $10 \%$ concentrate $(30 \%$ crude protein/ $\mathrm{kg}, 9.2 \mathrm{MJ} \mathrm{ME} / \mathrm{kg}, 5.1 \%$ fibre), $20 \%$ wheat middlings ( $>9 \%$ fibre) and $70 \%$ of coarse grains (wheat $15 \%$, barley $40 \%$, oats $15 \%$ ) for pregnant sows to 90 days of pregnancy (overall, 11.6 MJ ME, $125 \mathrm{~g}$ crude protein); and all-mash containing 17.5\% concentrate $(36.6 \%$ crude protein $/ \mathrm{kg}, 11.3 \mathrm{MJ} \mathrm{ME} / \mathrm{kg}, 4.5 \%$ fibre) and $82.5 \%$ of coarse grains (wheat $35 \%$, barley $40 \%$, oats $7.5 \%$ ) for pregnant sows from 91 days of pregnancy and nursing sows (overall, $12.7 \mathrm{MJ} \mathrm{ME}, 160 \mathrm{~g}$ crude protein).

Average feed intake for sows did not show significant differences between groups and amounted to $3.2 \mathrm{~kg}$ for pregnant sows from 91 days of pregnancy and $7.4 \mathrm{~kg}$ for nursing sows during the 32-day lactation. From 10 days, piglets were fed prestarter mixture containing $18 \%$ crude protein and $13.8 \mathrm{MJ} \mathrm{ME}$ in $1 \mathrm{~kg}$ of feed. Sows and piglets had continuous access to drinking water.

Polymorphism at the RYR1 locus was established using the PCR-RLFP method (Fujii et al., 1991). The biological material comprised gilt hair bulbs. DNA isolation was performed using Sherlock AX kit (A\&A Biotechnology) according to the manufacturer's protocol. PCR amplifications were performed in a PTC-200 Peltier thermal cycler (MJ Research Engine). The proportion of $R Y R 1 \mathrm{C} / \mathrm{C}$ and $R Y R 1 \mathrm{C} / \mathrm{T}$ genotypes in each group was $1: 1$. The sows were mated naturally to purebred boars of $R Y R 1 \mathrm{C} / \mathrm{C}$ genotype.

Three groups of experimental temperatures were established: $\mathrm{I}-22^{\circ} \mathrm{C}$ (constant temperature), II $-25^{\circ} \mathrm{C}$ (temperature range of 22 to $25^{\circ} \mathrm{C}$ ), III $-28^{\circ} \mathrm{C}$ (temperature range of 22 to $28^{\circ} \mathrm{C}$ ). Higher ambient temperature was obtained with 250 -watt heat lamps, the most common source of heat for piglets. The experimental factor was introduced temporarily from 10:00 to 14:00 h for 7 days pre-farrowing, on the farrowing day and on days 2 and 3 of lactation. Relative humidity of the rooms was maintained throughout the period at the optimum level of $70 \%$.

Microclimatic parameters, such as temperature and moisture, were measured using a thermo-hygrometer (RT811E, Technology Warsaw, Poland) placed in a pen with monitoring, which allowed for constant control.

Reproductive value was estimated based on the indices established in the second and third reproductive cycle including delivery date, number of piglets born alive and stillborn piglets, litter size on days 7,14 and 21 of age, piglet mortality rate at weekly periods from 1 to 21 days of age, piglet body weight determined at 7-day intervals from 1 to 21 days of age, sows' milk yield, and chemical composition of colostrum and milk. In addition, evaluation was made of the maternal behaviour of sows towards neonatal pigs on the first day of life. Direct observations from the onset of delivery until the end of the first day of piglet life showed cases where a sow savaged or crushed a newborn pig. The result was presented as a mean value per hour.

Colostrum and milk samples were collected on 1, 7, 14 and 21 days of lactation after intravenous administration of $15 \mathrm{IU}$ of synthetic oxytocin. The samples were always taken from the same teat pairs. A Milko-Scan 104 device was used to estimate the percentage of the following major components of sow's milk: fat, protein, lactose and solids. Somatic cell counts (SCC) were determined with a Somacount 150 instrument. The estimated numbers of somatic cells were converted into natural logarithm (LOG). 
Significance of differences for the level of productive traits was verified by multi-factor analysis of variance, the least squares method and the mixed model analysis, using the following statistical model:

$$
y_{i j k l}=\mu+G_{i}+R_{k}+i(h y s)+f+e_{i j k l}
$$

where:

$y_{i j k l}-$ value of observed trait;

$\mu-$ mean value of trait;

$G_{i}$ - fixed effect of temperature;

$R_{k}$ - fixed effect of genotype at $R Y R 1$ locus;

$i$ (hys) - interaction between herd and year and month;

$f$ - effect of father of litter;

$e_{i j k l}-$ random error.

The calculations were performed with the SAS statistical program. The level of the analysed traits was presented as the least squares means (LSM) with concomitant standard error (SE) values that define the reliability of estimation.

\section{Results}

The data summarized in Table 1 indicate that both sow genotype and temperature in the pen were associated with the level of reproductive efficiency parameters. The sows showed a tendency towards prolonged farrowing along with periodically increasing ambient temperature. In the $\mathrm{C} / \mathrm{T}$ group, staying in a pen with a periodic temperature of $28^{\circ} \mathrm{C}$ increased the duration of parturition by $1.27 \mathrm{~h}$ compared to a temperature of $22^{\circ} \mathrm{C}$. In the $\mathrm{C} / \mathrm{C}$ group the difference between the corresponding groups reached $2.64 \mathrm{~h}$ and was statistically significant $(\mathrm{P} \leq 0.05)$.

Sows held periodically at temperatures of $25^{\circ} \mathrm{C}$ and $28^{\circ} \mathrm{C}$ showed a higher number of aggressive behaviours and crushing. In genotype groups, maternal behaviour decreased with increasing temperature. More incidences of savaging and/or crushing were shown in the heterozygous compared to the homozygous sows (Table 1).

In the sows of both $\mathrm{C} / \mathrm{C}$ and $\mathrm{C} / \mathrm{T}$ genotypes fertility traits were observed to decrease with rising air temperature above the threshold value of $22^{\circ} \mathrm{C}$, recognized as the optimum. At the thermal optimum more piglets were born alive compared to sows maintained at $28^{\circ} \mathrm{C}$. The differences proved to be highly significant $(\mathrm{P} \leq 0.01)$ for the $\mathrm{C} / \mathrm{C}$ and significant $(\mathrm{P} \leq 0.05)$ for the $\mathrm{C} / \mathrm{T}$ genotypes (Table 1 ).

The sows from all groups had fewer stillbirths when farrowing at a temperature range of 22 to $25^{\circ} \mathrm{C}$. On day 7 of age of piglets housed at both optimal and increased $\left(28^{\circ} \mathrm{C}\right)$ temperature, litter size was higher in the $\mathrm{C} / \mathrm{C}$ group compared to the $\mathrm{C} / \mathrm{T}$ group, which could also result from their higher fertility (Table 2). 


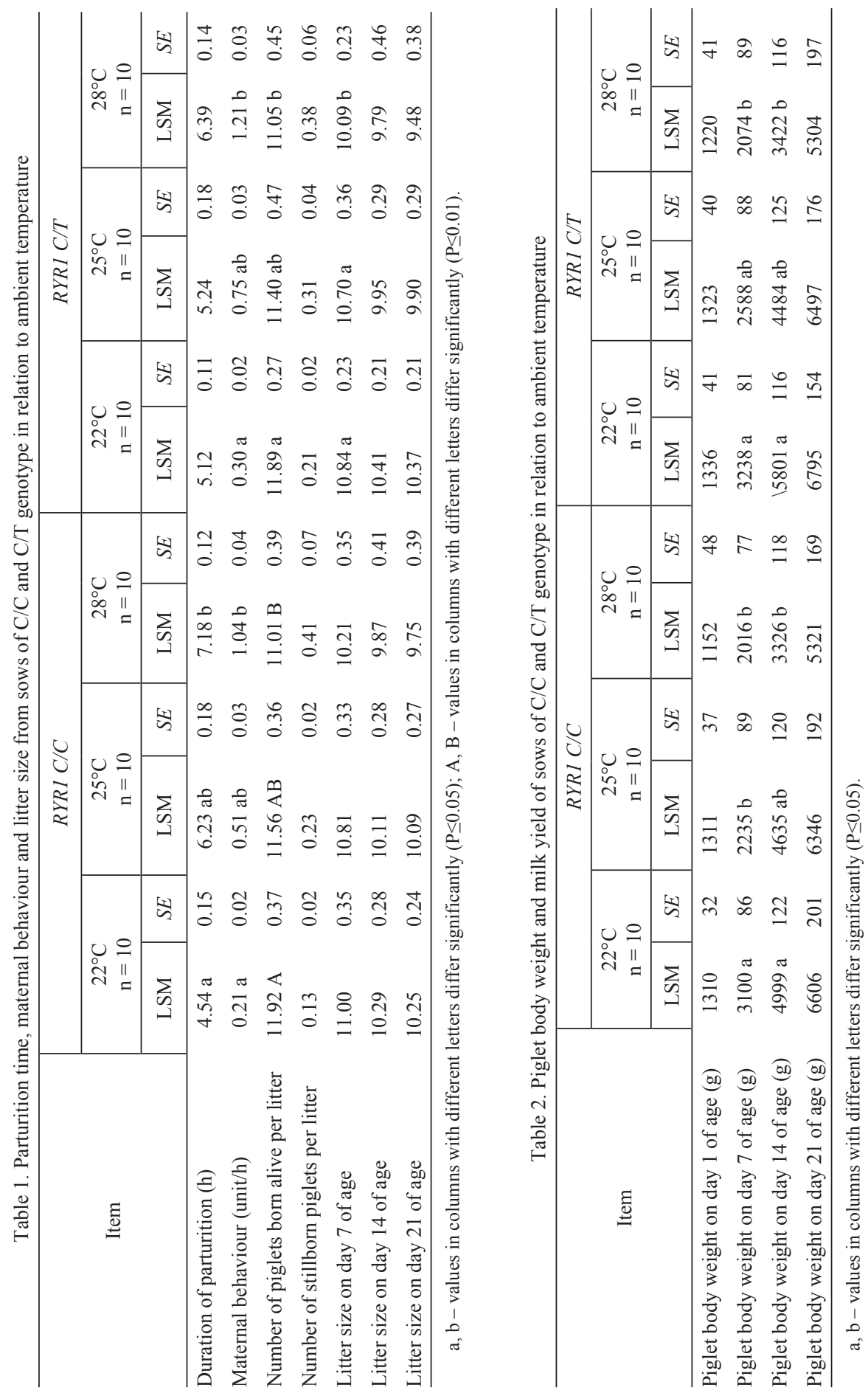




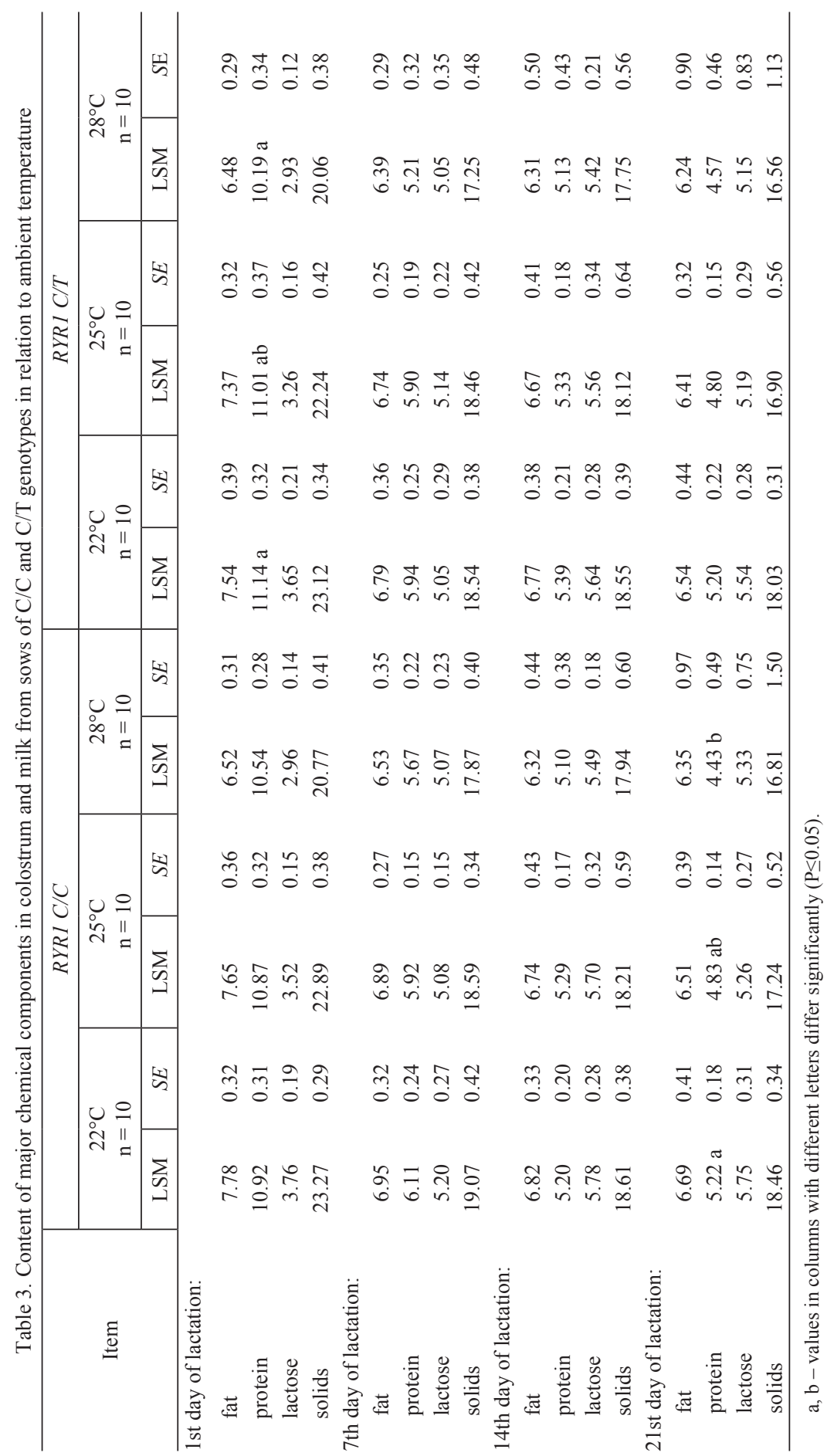




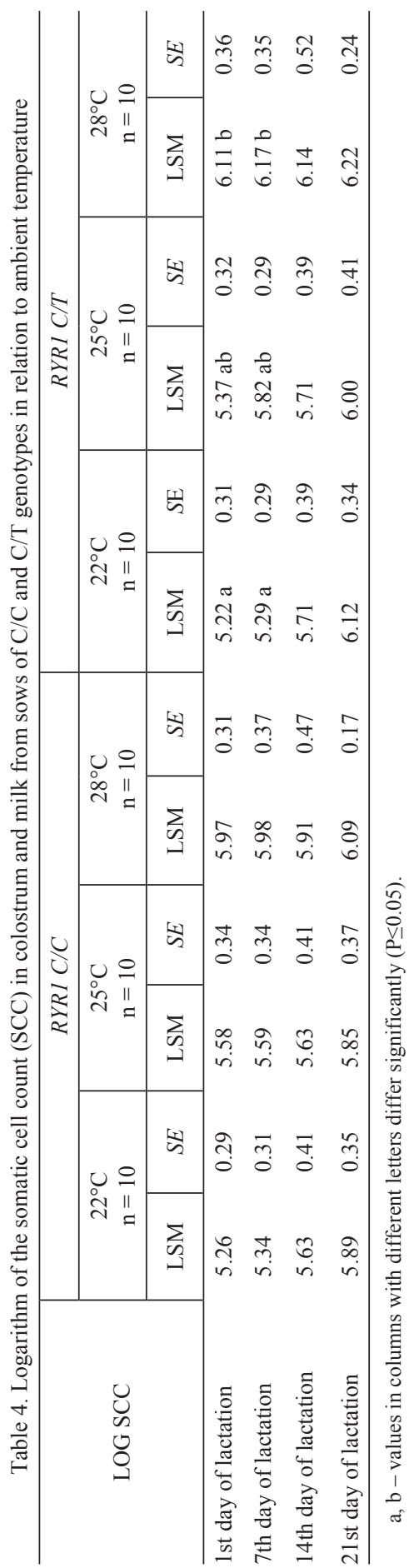


At $22^{\circ} \mathrm{C}$ the highest body weights were found in the litters from mothers of $\mathrm{C} / \mathrm{T}$ genotype. This finding, however, was not confirmed for higher temperatures. The weight of piglets at the age of 14 and 21 days was higher in the $\mathrm{C} / \mathrm{C}$ groups at $25^{\circ} \mathrm{C}$ and $28^{\circ} \mathrm{C}$.

The study confirms the variability of the chemical composition and SCC of colostrum and milk under varying ambient temperatures (Tables 3 and 4). Solids content was lowest in the colostrum and milk from sows at $28^{\circ} \mathrm{C}$ and highest in sows at $22^{\circ} \mathrm{C}$ (Table 3). A similar tendency was found for protein and fat content. Significant differences were demonstrated in colostrum protein quantity on day 1 of lactation in the $\mathrm{C} / \mathrm{T}$ sows at $22^{\circ} \mathrm{C}$ and at $28^{\circ} \mathrm{C}$ as well as in milk on day 21 of lactation in the $\mathrm{C} / \mathrm{C}$ sows $(\mathrm{P} \leq 0.05)$. The lowest lactose concentration was found at $28^{\circ} \mathrm{C}$ on days 7 and 14 of lactation.

In the analysed colostrum and milk samples, the somatic cell count in each lactation period was the highest for the sows at $28^{\circ} \mathrm{C}$ (Table 4).

\section{Discussion}

The domestic pig shows no morphological adaptation to maintain a constant body temperature in response to rapid changes occurring in the environment. Compared to other species of farm animals, the pig is very sensitive to elevated temperature because the form of sweat glands it has on the skin does not work and thus, does not facilitate heat loss (Huynh, 2005). Ambient temperature in a pig facility proves to be a key element affecting animal welfare and thus influencing animal production performance.

The results summarized in Tables 1-4 show that ambient temperature exceeding $25^{\circ} \mathrm{C}$ may be one of the factors affecting the value of reproductive sows. Heat stress in the late gestation and exposure to thermal stress may be a direct cause of fetal mortality (Bloemhof et al., 2008).

As demonstrated in our study sows at $28^{\circ} \mathrm{C}$ gave birth to many dead piglets on average. The reasons for this fact may be found in the metabolism. Under the influence of stressors, the body takes a number of actions aimed at environmental adaptation. The pituitary-adrenal axis is stimulated to increase the amount of glucocorticoids in blood plasma, which is beneficial through the launch of lipolysis and delivery of energy to the process of adaptation. Stressors have long-term effects on the persistence of high levels of glucocorticoids, which is one reason for weakening the body's immunological barriers and negatively affects fetal life processes (Stalder and Conatser, 2009).

The data in Table 2 showed differences in body weight between groups of piglets from $22^{\circ} \mathrm{C}$ and $28^{\circ} \mathrm{C}$ on the day of birth. Such a distribution of values could result from the action of mother's stressors on the fetus, which could lead to reduced transfer of nutrients in the mother - fetus system. While appearing on the first day of life, variability could also cause an increasing difference in piglet body weight at 7, 14 and 21 days. 
An important element of the initial phase of rearing piglets, such as determining of litter size and its weight is the chemical and cytological composition of colostrum and milk (Auldist et al., 2000; King et al., 1997; Toner et al., 1995; Walkiewicz et al., 2001). Variability in the concentration of the major components during lactation is dependent on genetic and environmental factors, which was confirmed in several studies (Rekiel and Więcek, 2003; Daza et al., 2004; Walkiewicz et al., 2006).

In the present experiment significant differences were observed in milk composition and SCC ranked sows in groups depending on ambient temperature and genotype at RYR1 locus. There was a general downward trend for each milk component (protein, fat, lactose and solids) with periodically increasing temperature in the sow's pen. It was also demonstrated that the milk lowest in chemical components was obtained from the sows housed periodically at $28^{\circ} \mathrm{C}$. More solids in the subsequent periods of lactation were found in samples from sows with $R Y R 1$ genotype $\mathrm{C} / \mathrm{C}$.

Somatic cells in colostrum and milk are one of the components, like protein, fat and lactose, which determine cytological properties of colostrum and milk. Rekiel and Więcek (2002) showed the relationship between SCC and the contents of selected macronutrients in milk of sows, which may translate into the rearing results of piglets, for which colostrum and milk are a source of nutrients. Important elements that influence the number of somatic cells are the conditions for animal housing and feeding. Increased levels of SCC may be associated with a sudden change in environmental conditions caused by the advent of stressors such as high ambient temperature. As stated in the colostrum and milk sample obtained from sows at periodically higher temperature ranges, they were characterized by an increased rate of LOG SCC. These relations primarily concern the sows of heterozygous genotype at the RYR1 locus (Table 4).

The impact of the $R Y R 1$ gene polymorphism on reproductive traits has been repeatedly addressed in research papers. Some of them, including the present study, indicate a negative influence of the T nucleotide at the $R Y R 1$ gene on litter parameters (Nyström and Andersson, 1993; Omelka et al., 2006). C/C sows were better adapted to high ambient temperature, had shorter farrowing time, larger litter size and heavier piglets throughout the lactation period. However, in the current literature one can also find some ambiguities that do not support the tendencies presented in Tables 1-4 (Kmieć et al., 2000; Buczyński et al., 2006) but may arise from differences in animal material and experimental design.

The present study confirms the occurrence of an unfavourable relationship between periodically increasing ambient temperature in the farrowing and postnatal periods and parameters of sow reproductive performance. Sows held periodically at $25^{\circ} \mathrm{C}$ or $28^{\circ} \mathrm{C}$ were characterized by longer farrowing, more aggressive behaviour, a higher number of stillborn piglets, and lower body mass in subsequent periods. A negative impact of the thermal factor on the chosen traits was also found in $\mathrm{C} / \mathrm{T}$ sows at the RYR1 locus. 


\section{References}

A u ld is t D.E., C a r ls on D., M or r is h L., W a k e for d C.M., K in g R.H. (2000). The influence of suckling interval on milk production of sows. Anim J. Sci., 78: 2026-2031.

B a b i c z M., K u rył J., W a l k i ew i c z A. (2003). Evaluation of the genetic profile of the Pulawska breed. J. Appl. Genet., 44 (4): 497-508.

B loem of S., V an der W a a ij E.H., Merks J.W.M., Knol E.F. (2008). Sow line differences in heat stress tolerance expressed in reproductive performance traits. J. Anim. Sci., 86: 3330-3337.

Brown-Brandl M., Eigenberg R.A., Ni enaber J.A., Ka chman S.D. (2001). Thermoregulatory profile of a newer genetic line of pigs. Livest. Prod. Sci., 71: 253-260.

Buczyńs ki J.T., P an ek A., K e m p is ty B., S krzy pczak E., Lu c iński P. (2006). Reproductive performance of Złotnicka White pigs as related to RYR1 gene. Anim. Sci. Pap. Rep., 24 (Suppl. 1): 43-50.

$\mathrm{Ch}$ ris t o n R. (1988). The effect of tropical ambient temperature on growth and metabolism in pigs. J. Anim. Sci., 66: 3112-3123.

D a z a A., Ri o pér e z J., C e n te n o C. (2004). Changes in the composition of sows' milk between days 5 to 26 of lactation. Spanish J. Agric. Res., 2: 333-336.

Fras e r A.F. (1970). Studies on heat stress in pigs in a tropical environment. Tropic. Anim. Health Prod., 2: 76-86.

Fuji J., Otsu K., Zorzato F., De Leon S., Khanna V.K., Weiler J.E., O'Brien P., M a c L e n n a n D.H. (1991). Identification of a mutation in porcine ryanodine receptor associated with malignant hyperthermia. Science, 253: 448-451.

H u y n h T.T.T. (2005). Heat Stress in Growing Pigs. Wageningen Institute of Animal Science, Wageningen University, Wageningen, The Netherlands, pp. 45-66.

K ing R.H., Multan B.P., D un she a F.R., D ove H. (1997). The influence of piglet body weight on milk production of sows. Livest. Prod. Sci., 47: 169-174.

K mi é M., Dw orrak J., V rtková I. (2000). Relations between the polymorphism in the ryanodine receptor gene (RYR1) and certain reproductive traits of sows in a herd of Polish Landrace pigs. Anim. Sci. Pap. Rep., 18: 277-283.

Malmkvist J., D a mga ard B.M., P edersen L.J., Jorgensen E., Thodberg K., Cha loupkova H., Bruckma i er R.M. (2009). Effects of thermal environment on hypothalamicpituitary-adrenal axis hormones, oxytocin, and behavioral activity in periparturient sows. J. Anim. Sci., 87: 2796-2805.

Nyström P.E., Anders s on K. (1993). Halothane gene effects on reproduction, production and organ weights in pigs. Acta Agric. Scand., 43: 101-206.

O m e lk a R., P e škovič ová D., M a rtini a ková M., B a u e r M., B a u e rova M. (2006). Effect of the estrogen receptor (ESR) and ryanodine receptor (RYR1) genes on reproductive traits of Slovak Large White, White Meaty and Landrace pigs. Arch. Tierzucht., 49: 357-362.

Prunier A., Messias de Bragança M., Le Dividich J. (1997). Influence of high ambient temperature on performance of reproductive sows. Livest. Prod. Sci., 52: 123-133.

Reki el A., W i ęc e k J. (2002). The interaction between somatic cell count (SCC) and content of chosen macro elements in sows' milk. Med. Weter., 58: 884-886.

R e ki e l A., W i ę c e k J. (2003). Characteristics of selected physico-chemical and cytological parameters of sow's milk. Ann. Anim. Sci., 3: 263-267.

Ren a udeau D., An a is C., Te 1 L., G ourdin e J.L. (2010). Effect of temperature on thermal acclimation in growing pigs estimated using a nonlinear function. J. Anim. Sci., 88: 3715-3724.

S t a ld er K., C on at s e r G. (2009). Porcine stress syndrome and its effects on maternal, feedlot and carcass quantitative and qualitative traits. Agricultural Extension Service, The University of Tennessee, pp. 1-12. Available at: http:/www.utextension.utk.edu/publications/pbfiles/PB1606 created 2009.

Toner M.S., King R.H., D uns he a F.D., Dove H., A two od C.S. (1995). The effect of exogenous somatotropin on lactation performance of first-litter sows. J. Anim. Sci., 73: 167-172.

Walki ew icz A., Kamyk P., Babicz M. (2001). Effect of parturition of sows fed oiled mixture on fat content and composition in colostrum secretion and milk. Annales UMCS, sec. EE, 31: 247-253. 
W a lki ew i c z A., K a s przy k A., B a b i c z M. (2002). Analysis of phenotypic variability and selection difference in traits of reproduction performance for PL sows from nucleus herd in Pukarzów from breeding district in Lublin. Annales UMCS, sec. EE, 20: 73-81.

Walkiewicz A., Kasprzyk A., B abicz M. (2006). The influence of induced parturition on pregnancy and chemical composition of colostrum and milk in three successive reproduction cycles of gilts. Anim. Sci. Pap. Rep., 24 (Suppl. 1): 71-80.

Accepted for printing 2 IV 2012

\author{
MAREK BABICZ, EWA SKRZYPCZAK, BARBARA REJDUCH, \\ ANNA KOZUBSKA-SOBOCIŃSKA, ANNA CHMIELOWIEC-KORZENIOWSKA, \\ KAROLINA KASPRZAK
}

\title{
Wpływ stresu termicznego na wskaźniki reprodukcyjne loch o ustalonym genotypie w locus $R Y R 1$
}

\section{STRESZCZENIE}

Celem przeprowadzonych badań i analiz było określenie oddziaływania temperatury powietrza w sektorze porodowym chlewni na skład chemiczny, liczbę komórek somatycznych siary i mleka oraz wyniki odchowu prosiąt loch rasy polskiej białej zwisłouchej o zidentyfikowanym genotypie w locus RYR1. Materiał zwierzęcy stanowiło 60 loch rasy polskiej białej zwisłouchej (pbz) w drugim i trzecim cyklu reprodukcyjnym. Analizę polimorfizmu w locus RYRl wykonano metodą PCR-RFLP. Liczebność genotypów RYR1 C/C i RYRl C/T w każdej grupie wynosiła 1:1. W zakresie temperatur doświadczalnych przyjęto trzy grupy: I $-22^{\circ} \mathrm{C}, \mathrm{II}-25^{\circ} \mathrm{C}, \mathrm{III}-28^{\circ} \mathrm{C}$. W przeprowadzonych badaniach wykazano, iż lochy utrzymywane w okresowo wyższej temperaturze otoczenia $\left(25^{\circ} \mathrm{C}, 28^{\circ} \mathrm{C}\right)$ wykazywały relatywnie dłuższy czas porodu, większą liczbę zachowań agresywnych i przygnieceń prosiąt. Stwierdzono również zmienność cech pomiędzy grupami w odniesieniu do liczebności i masy miotu, składu chemicznego i LKS siary oraz mleka. Uzyskane wyniki wskazują, iż podwyższona temperatura otoczenia w okresie okołoporodowym może mieć niekorzystny wpływ na wartość użytkową loch. 